\title{
Adherence to Abagirwa's Shamanism and its Effects on Anthropological Status. Case Study of Mad People of Gitenga Cell, Kiyombe Sector, Nyagatare District 2016-2017
}

\author{
Father Dr. Hakizimana Lucien, Nkeramugaba Anicet, Rutayisire Felix
}

Department of Social Sciences, University of Technology and Arts of Byumba (UTAB), Rwanda

\begin{abstract}
This research was about the adherence to abagirwa's Shamanism and its effects on anthropological status. The main objective of this research was to find out the reason of which in Gitenga Cell are registered many mad. We ran with hypotheses according to which to practice abagirwa's shamanism should be the reason of the high presence of mad in Gitenga Cell. To make a hermeneutic and critical approach, the methods used in collection, analysis and interpretation of information are qualitative and quantitative.

Findings from our respondents revealed different problems in practitioners of Abagirwa's shamanism: alcohol abuse $80 \%$, cases of suicide or attempt to suicide $68 \%$, incest $46 \%$, divorce $90 \%$, the parents who do not care about the health of their children 65\%, clinical depression 100\%, lack of self-control 84\%, psychological distress 100\%, mad people's psychoses 100\%, necromancy (conjuring the dead) 45\%, denial of the efficiency and effectiveness of pharmaceutical medicines $80 \%$, alienation $100 \%$.

Suggestions for anthropological wellbeing: education to help them to change their behaviors, interventions of local and opinions leaders and to deepened traditional healing and its medicines with scientific and rigorous methods so that to avoid disappointing practices.
\end{abstract}

Keywords: Shamanism, abagirwa, adherence, anthropological status, practitioners

\section{INTRODUCTION}

In traditional societies people with high levels of paranormal and religious beliefs may project an aura of spirituality and religiosity and, as a result, may be conferred shamanic or shaman-like status. Among them could be found healers, medicine men, seers, sorcerers. Their role within a traditional society may include physical and psychological healing, but also divining the weather, following totemic animals, communing with the spirits, and placating the gods. ${ }^{1}$

This situation is lived in Gitenga Cell where many people experience shamanism through abagirwa, servants of miss Nyabingi who hand over through generation her religious spirit. So, psychotic people are reported in a great number on this location.

Gitenga Cell has been a homeland of Miss Nyabingi venerated in the hill of Muhinda where we find the sanctuary frequented by many people from ancient time.

Traditionally, the most popular spirit among the bakiga of southwest Uganda and neighboring part of Rwanda is that of respected rainmaker called Nyabingi whose home was found in 18th century in Mukante in the Bufundu Hills of the Rwanda-Uganda borders. The sacrifices began to be offered to Nyabingi after her death and those sites began to be visited by numerous people to implore her protection, because this spirit was thought to possess the powers of healing, rainmaking and curing infertility and other diseases.

This research was conducted with the purpose of investigating the relationship between the madness and the practices of abagirwa's shamanism in Gitenga Cell; finally we worked on the strategies for effectiveness of anthropological well being.

\section{MAterials AND MethodS}

This research was location oriented and qualitative and quantitative methods were adopted. The specific survey tools used were: focus group discussions, interviews, questionnaire and observation.

${ }^{1}$ Neel Burton M.D., 2012:19. 


\section{Dr. Hakizimana Lucien et al.}

In attempt to understand mad people on their lifestyle on each question, how each of them feels, experienced the situation of own madness, his problems and the factors of madness affecting him or her, the historical approach was used.

The focus group was formed for the discussion about different themes among the persons who experienced madness mainly for the causes of their current situation, the effects of madness on their anthropological status and their family members. As said Eliot \& Associates, focus group is a small group of six to ten people led through an open discussion by a skilled moderator. ${ }^{2}$ It is a type of qualitative research methodology used to generate qualitative data on a precise topic of interest, using a set of open-ended questions. ${ }^{3}$ So, 31 persons formed four focus groups. 10 were the members of the families of mad people and 21 in 3 groups were the mad persons in recovery status. The qualitative data collected were about the relationship of belonging to abagirwa's shamanism and the madness. We used qualitative research which provided us aspects of human life such as culture, expression, beliefs, morality and imagination. ${ }^{4}$

Those whose families have one mad were 13 , those who have more than two mad people were 8 . Their age varies between 18 years old and 45 . Those under 25 years old on focus group were 4; those between 25-30 years old were 5; those between 31-35 years old were 5; those between 36-40 years old were 6 and those over 40 were 11. Female were 23 and the male were 8 .

To obtain more information from mad people or people who experienced madness the purposive sampling was carried out through in depth interview. Purposive sampling is especially exemplified through the key informant technique ${ }^{5}$ wherein one or a few individuals are solicited to act as guides to abagirwa's shamanism culture. Key informants are observant, reflective members of the community of interest who know much about the culture and are both able and willing to share their knowledge ${ }^{6}$

In-depth interviews are useful when you want detailed information about a person's thoughts and behaviors or want to explore new issues in depth. Interviews are often used to provide context to other data (such as outcome data), offering a more complete picture of what happened and why ${ }^{7}$ The deep interview was conducted to 10 persons from whom 5 have the level of primary, those with the level of secondary school were 3 , one has the level of university and 1 has the orientation level. Those people who are key informant experienced the problem of mad persons from 2002 and live near them. We asked participants, staff, and others associated with the shamanism about their experiences and expectations related to shamanism, the thoughts they have concerning its operations, processes, and outcomes, and about any change they perceive in themselves as a result of their involvement.

The questionnaire was addressed to the 30 persons concerned by focus group among them 25 neighbours chosen on basis of the problems caused by mad people living near them. Those 25 persons are aged of 25 to 65 years. Three of them have university level of education; 5 have the level of secondary school; other have either the level of primary school or frequented vocational training center.

Codes were used in the interview in order to keep secret the responses provided by them and for ethical consideration. So, the opinions and ideas of the interviewees were welcome. The confidentiallity of the information was kept. To conduct the interview and focus group discussion, an interview and focus group guide designed by the researchers were used.

\section{RESUlTS OF THE RESEARCH}

\subsection{Anthropological Problems of Practitioners of Abagirwa's Shamanism}

As specify the results of this research, $80 \%$ of respondents affirmed that the alcohol abuse is reported among practitioners of shamanism through abagirwa. The alcohol consumption is reported in different practices. So, there are some practitioners who are asked to drink harmful drinks as a sort of medication which accompanies other rites. They abuse the alcohol even when they are asked to skip medicines during drug taking.

\footnotetext{
${ }^{2}$ Eliot \& Associates. 2005:1.

${ }^{3}$ Mousa A. Masadeh, 2012:63-67.

${ }^{4}$ Wertz, Charmaz, McMullen 2011:16-18.

${ }^{5}$ Bernard 2002:146.

${ }^{6}$ Bernard 2002:147.

${ }^{7}$ Carolyn Boyce et Palena Neale, 2006:3.
} 
According to the results, $68 \%$ of the respondents and even family members of practitioners and their neighbors reported many cases of suicide or attempt to suicide among the ancient practitioners. In fact, when they fall mad they commit suicide and this has as consequences the fear of many other people. The abandonment, harassment and isolation are indexed as major causes of suicide.

Child and women abuse on different forms such as child neglect, sexual abuse, child marriage,... are reported in the community as problems faced by the practitioners of those religions by $70 \%$ of the respondents.

The incest between sister and brother is indexed also by $46 \%$ of the respondents. In fact, in different interview we saw that those abuses are results of misunderstanding between practitioners of religions or they are the conditions obliged by abagirwa.

$90 \%$ of the respondents revealed that the divorce or attempted to the divorce is pointed out on many cases when the misunderstanding between the husband and the women concerning the practices arise. When one of them accepts to become a Christian immediately the divorce is declared. When also there is an undesirable practice the couple can divorce. The examples quoted here are abortion, unsafe sexual intercourse, incest,... The divorce occurs also when one of the married couple can no longer support or bear the illness of another.

Considering also what we found during the interview, the parental neglect is revealed as a crucial anthropological problem faced by traditional practitioners in considerable situation. There are cases where the parents do not care about the health of their children, they abandon them, they don't support their studies... this was testified by $65 \%$ of the respondents.

\subsection{Psycho-Anthropological Problems of Practitioners of Abagirwa's Shamanism}

The reflective anger is reported as a psycho-anthropological problem met by practitioner of abagirwa's shamanism. When a practitioner meets a social or economical problem with neighbors he is taken by an excessive anger so that the revenge is foreseen as remedy. When he has a problem, he can have recourse to a destruction of the houses, crops, the ideas of murder appears... such cases are reported by $72 \%$ of the respondents.

$100 \%$ of the respondents revealed that clinical depression is experienced by mad people. In fact they said when they are falling ill it is the symptom of crisis. So, the depression is felt by them.

$100 \%$ disclosed that excessive amount of self-control of the neighbors by fearing to be victims of poison; the neighbors to meet, the way to pass, the food to eat, is greatly felt by the practitioners. In fact they fear everything so that they control whatever they meet.

A lack of self-control for some practitioners is reported by $84 \%$ of the respondents. Respondents, reveal that practitioners lack control when they are in crisis so that they can circulate naked. They can't control their words, their gestures, theirs actions so that this can have as consequences the lateness in their reactions or the brutality.

As shown by the results $100 \%$ of the respondents, psychological distress is felt by the practitioners when for example they are asked to find the sacrifice such as the cow for the spirit. This stress exposes them to different thoughts up to be surpassed by the situation. This stress for some practitioners leads either to the lack of self control or to excessive control.

As announced $100 \%$ of the respondents, the mad people feel psychoses. Some of them said sometimes they feel seeing, hearing, smelling, or tasting things that are not there; they have also delusional thoughts. This for them appears periodically. There are some of them who said that when they meet some family members who are thought to practice this shamanism those symptoms appear. The symptoms of psychoses appear mainly when their relatives are thought to have contacted the active practitioners. Some of the interviewees said the signs of psychoses increase from the apparition of abarangi in the entity. Is it because the bad spirits from abagirwa and those from abarangi were in collision? They support to be the healers of the diseases related to bad spirits. But in fact according to the responsible of CEB, the Christians who frequent them can't denounce what they saw by fearing the consequences.

Delusion behaviors are quoted by $79 \%$ of our respondents among many practitioners or ancient practitioners of abagirwa's shamanism. Some respondents said they sometimes believe that they are 


\section{Dr. Hakizimana Lucien et al.}

violated by others, that someone close to them is about to die, a friend is really a government agent, etc. The persons who are still in the state of crisis are characterized by the fear of some neighbors. In fact they suspect them to be on the origin of their illness and situation of madness. For the interviewees those behaviors have their origin from indoctrination of abagirwa who instead of curing them they ask them to make some practices with the aim of chasing the bad spirit. Unfortunately they forbid them to consult modern medicines.

\subsection{Practices of Abagirwa's Shamanism}

In abagirwa's shamanism the practice of healing is reported by $100 \%$ of the respondents. The healing uses traditional medicines and some incantations. They cure while being in practices such as kuragura ${ }^{8}$ where they recommend to the persons in consultation to offer some gifts in order to benefit the favors from ancestors.

Witchcraft exists in the traditional practices up to now as affirmed $74 \%$ of the respondents. Many people deny the current existence but those who have practiced agreed the practice nowadays. This practice goes with the divination where people are heard by the umugirwa known in the location. Unfortunately any mugirwa can't provide information about their practice. Their neighbors affirmed that the practice goes on. As in the location we have some people who stopped to take medicines, we were informed by the CEB (Communauté Ecclésiale de Base) responsible that those bagirwa are frequented by the skippers of medicines.

Different respondents in the focus group said they have frequented men who advertised enchantments, operates miraculous incantations, make charms for their love-affairs, hold visitations for their enemies, intervene in disclosures of buried treasure and successions to estates, prophetic dreams.... They said that the persons consulted were in the hills of Muhinda. The members of the families of the first bagirwa continued these activities at their death even when the sanctuary of Muhinda was destroyed. While consulting the spirit they said abagirwa use sticks, stones, bones, beans, coins, or some other items. This was also confirmed by $72 \%$ of our respondents.

Different people questioned said that in this location, abagirwa as malicious magic users, are cause of disease, sickness in animals, bad luck, sudden death, impotence and other such misfortunes. This was confessed by $61 \%$ of our respondents. They said that more people believe that their witchcraft may then be employed to turn the malevolence aside, or identify the supposed evil-doer so that punishment may be carried out. Abagirwa use folk magic to identify or protect against malicious magic users. They can harm anybody offered or accused by another.

$73 \%$ of the respondents said abagirwa use spelling, the word used to signify the means employed to carry out a magical action. So our respondents said the witches use a set of words, a formula or verse, or a ritual action. Those spells are used by different methods such as, by the immolation or binding of a wax or clay image of a person to affect him or her magically, by the recitation of incantations, by the performance of physical rituals, by the employment of magical herbs as amulets or potions, swords for purposes of divination and by many other means.

Necromancy (conjuring the dead) is also used as acknowledged by $45 \%$ of the respondents. So this practice consists in conjuring the spirits of the dead for divination or prophecy. Those spirits are invocated in order to produce the peace in the society but also to punish the enemies of the family. Some persons still in crisis but who seem to be in a healthy mood, said that when the spirits of ancestors are not satisfied because they are not venerated, they cause troubles in society.

\section{DisCUSSION OF FINDINGS}

Attached to abagirwa's shamanism as they are more exposed to mental disorders that may lead to madness This research had the main purpose of establishing the relationship between anthropological effects of madness and adherence to abagirwa's shamanism in Gitenga Cell, Kiyombe Sector in Nyagatare District. We have been motivated by the fact that this region of Gitenga host many cases of mad people since long time and the hypotheses is that the madness should be caused by adherence to abagirwa's shamanism. In this locality, it is experienced the increase of the number of mad people from 2012. They have been supported by Caritas of Nyarurema parish from long days. This number grew from 25 up to 93 of mad people supported from 2012 up to 2017. According to 55\% of our

\footnotetext{
${ }^{8}$ Kuragura is to practice the divination, employing witchcraft, or trying to communicate with the dead.
} 
respondents, a great number of mad people are not concerned by the support because they are hidden by their families or they ignore such assistance provided by Caritas to accompany them.

Taking into account what we have found on the field throughout the interview and other techniques used in data collection that we have mentioned above in methodology, many cases of madness originate from the adherence to abagirwa's shamanism. Spirits were consulted mainly in paranormal situations for requesting a special help from them. ${ }^{9}$ This region in the last times has been the homeland of Nyabingi and her relevant rites. Is it because some people have rejected their abagirwa's shamanism that we find there many cases of madness? Is it because they are experiencing economic decline so that they cannot find means to satisfy their rites requirements? Is it because modern society is not tolerating these practices nowadays and this causes frustration and depression to practitioners? Many questions can rise.

The results of this study support the original hypotheses: "The adherence to abagirwa's shamanism should be the cause of madness as effect".

The listed above problems faced by mad people in Gitenga Cell are going to be reviewed and supported by relevant literature review with the intention to demonstrate the fact that as people are.

\subsection{Social Consequences of Shamanism of Abagirwa}

\subsubsection{Harm to Individuals}

The field research revealed that the inadequate medical care is one of consequences of shamanism of Abagirwa. $80 \%$ of respondents testified that the abagirwa's shamanism practitioners used the herbal medicines from the forest and deny the efficiency and effectiveness of pharmaceutical medicines. This adherence to abagirwa's shamanism and negligence of modern medicines push the individual to unhealthy medical condition. People die in their home waiting to be healed by their spirit.

While many people go to modern medical facilities for treatment due to the influence of Westernization and Christianity, many will seek a second opinion from an herbalist or a diviner, while others seek divine intervention through prayers. ${ }^{10}$

Taking into account what said by many interviewers, the transportation of problems is a wide consequence of abagirwa's shamanism. They judge others as responsible of their unlucky doing. For example, in the case that one married couple met the reproduction problem, they transport the issue and said that it is caused by the anger of their forefathers. The transportation may lead to misunderstanding and queries with neighbors. In many African communities, when someone falls sick, the question of who might have caused it is at the back of people's mind. ${ }^{11}$

Abagirwa's shamanism leads to sexual disorder where there are cases of sexual intercourse with other people who represent the spirits. It has been reported also that, during the ceremonies women are excited by giving them the alcoholic beer.

The interviewers also revealed the cases of blood sacrifice in abagirwa's shamanism in many forms. The first born were presented as a gift to the sprits and they were sacrificed for the good and mercy of their families. The ladies are presented to abagirwa and they were denied all rights to marry to whom they wish or as they wish. These are major forms of sacrifice found in abagirwa's shamanism form.

Considering what we have observed at the field, the lack of hygiene is a harm that mad people are experiencing. The fact that they cannot care about themselves, they are abandoned and the reason that they live in a poor condition lead to a lack of hygiene that leads to diseases.

\subsubsection{Harm to Society}

The behaviors of abagirwa's shamanism practitioners lead to violence and social insecurity. $100 \%$ of the respondents supported this view. The rights of women and children are not respected; they are violated in some situations till to die. The problem of poison among people is also a key launcher of individual and community violence. All these issues bring out to insecurity where some are killed

\footnotetext{
${ }^{9}$ Gerard Niyomugabo, 2013:57.

${ }^{10}$ Michael C. Kirwen, 2008:193

11 Michael C. Kirwen, 2008:215.
} 


\section{Dr. Hakizimana Lucien et al.}

fought or beaten as victims of act of revenge. Some houses were burned and other people were chased out from their villages.

As results of violence and insecurity, the conflicts are too experienced among abagirwa's shamanism practitioners. The testimony from the person interviewed show that the conflict persists as consequence of abagirwa's shamanism. For example, families that are known as living in abagirwa's shamanism are isolated and none of their neighborhood can ask water to drink in those families.

Alienation also is a consequence of abagirwa's shamanism in the case that alienation is understood as an individual's estrangement from his community or society. This point of view was shared by $100 \%$ of the respondents. They live in passive life and they cannot live their thoughts.

Considering what we have heard during the interview with the mad people, many deny the scientific progress by neglecting the healing capacity of pharmaceutical medicines that they receive for their treatment. They say that medicines are there to destroy their normal functioning, to disturb and inhibit their reproduction. They cannot praise any progress out of their traditions.

Abagirwa's shamanism may lead to poverty. To accomplish the ceremonies recommended by their shamanism, they have to spend their financial resources in order to get offerings like cows, hen, goats and bears. The time spent during ceremonies is also involved as a factor leading to their poverty as they cannot work for themselves. For these who are mad they spend much time in abagirwa's house, the money spent on their treatment exceeds their house income. For reconciliation and restoration of broken relationship between the person and the spirits the drinks and meats of cattle were offered, people could give all they have for a single favor. ${ }^{12}$

\subsection{Psychological Effects}

Cognitive dissonance: Abagirwa's believes affect the practitioners psychologically. As said by the totality of family members of mad people their thoughts become vague and flux as the mad person cannot control and dominate him/herself. For example, it occurs that the person with madness can mix traditional and pharmaceutical medicines. Another issue is that the same person can forget quickly, not recognizing what she/he has said.

The neighbors of practitioners said that group attraction among initiates has been remarked as effect of traditions on the mentality; by the fact that the initiates build among themselves as group solidarity and attractions that brings to exclusion of non-initiated people. When they find themselves in another group they feel disappointed and disturbed. Conformity among new members and feelings of affiliation are major features of that group attraction. So, this prevents the practitioners to provide information fearing to be on their part isolated from the community. The "I'" is not the point of departure, but the "You", the "We", the collectivity of a community and tribe. ${ }^{13}$

Through this research we found that isolation is widely seen as effect of these abagirwa's shamanism believes as well as a symptom of madness for the practitioners. They are found isolated cross the villages for many reasons. First, because people around are afraid to be contaminated or poisoned. Second, because people has fear to approach the mad people. Even if these reasons are not exhaustive, the problem of isolation stills a crucial effect.

As we have mentioned in consequences of abagirwa's shamanism, alienation is a psychological effect of their practices. Mad people are out of their mind and they cannot as well as possible control what they say and do.

Anxiety is seen also as undeniable psychological effect. Many mad people experience it; their anxiety can include changes in sleeping patterns, nervous habits, and increased motor tension like foot tapping.

It has been revealed also that bipolar disorder is among psychological effects of their practices where the mad people manifest the periods of elevated mood and periods of depression. They feel or act abnormally happy, energetic, or irritable. They often make poorly thought out decisions with little regard to the consequences. ${ }^{14}$ The need for sleep is usually reduced. During periods of depression there may be crying, poor eye contact with others, and a negative outlook on life.

\footnotetext{
${ }^{12}$ L. Magesa 1997:215.

${ }^{13}$ Martin K. Nkemnkia, 1999:112

${ }^{14}$ Picchioni MM, Murray RM 2007:92.
} 
The emotional effects of anxiety may include feelings of apprehension or dread, trouble concentrating, feeling tense or jumpy, anticipating the worst, irritability, restlessness, watching (and waiting) for signs (and occurrences) of danger, and, feeling like your mind's gone blank as well as nightmares/ bad dreams, obsessions about sensations, and feeling like everything is scary. The cognitive effects of anxiety may include thoughts about suspected dangers, such as fear of dying. ${ }^{15}$ In order to appropriate the favors from the population, responsible of this shamanism creates the confusion up to distracting others in order to limit the level of participation.

\subsection{Spiritual effects}

Many respondents who have consulted abagirwa for their health care have obsessive devotion and obsessive guilt. They said they experienced groundless fear of sinning that arises from erroneous ideas a person's obsessions focus on moral or religious fears, such as the fear of being an evil person or the fear of divine retribution for sin. Although it can affect nonreligious people, it is usually related to religious beliefs. They often say that the persons who consult the spirit or who go to this shamanism don't want to approach the others. In fact they are accused by others to be full of sins and impurity.

Narrow-mindedness was remarked as spiritual effect. Different respondents said they are bigoted in their believes on abagirwa's shamanism. So they said before they were characterized by restricted or rigid views, they were unreceptive to new ideas. Some of them questioned among those who skipped medicines they are intolerant. This intolerance was discovered to be related to the fact they frequent the abagirwa's shamanism for their cure. They don't want any person to approach them.

The inflexibility characterizes the practitioners of abagirwa's shamanism. They don't want to change as said one respondent who has an umugirwa as mother. He is even attacked by the spirits when he talks about the spirits of her mother. They don't want to change in fact because they win money from activities related to their shamanism such as divinatory, augury, sorcery,...

\subsection{Impact on Anthropological Status}

During the interview we have remarked that spiritual possession is one of impact of believes on anthropological status. The interviewers revealed that practitioners experienced the time where they are out of their minds. Therefore, they are under spiritual possession that brings out to problems such as alienation and delusion. Anthropologically they are no longer normal. This was confirmed also by $82 \%$ of our respondents.

Considering our findings during the research, the clinical delinquency accompanied by depression is experienced among impact on anthropological status of practitioners of abagirwa's as well as among symptoms of madness. Mad people are found scavenging and circulating around; this impacts their anthropological stability. $89 \%$ of the respondents said also to have experienced such behaviors.

In the locality, many people, ancient practitioners of abagirwa's shamanism believe that the abortions often seen in their location are due to the requirement of the spirit. So, when the spirits need as victims a child they can even ask the aborted one. An abnormal rate of abortion is reported by different local leaders interviewed. $82 \%$ of our respondents testified also the fact of abortion in many families of practitioners. This in reality stops the development and alienates the society.

Sexual relationships outside of marriage are pointed out by the respondents as impact on anthropological status. The interviewers pointed out the fact that the sexual relationship outside the marriage is result from these believes. The reality is that sometimes to be treated these shamanic healers ask sexual intercourse as payback. Another reality is that some are requested to have sexual intercourse with abagirwa. When one of the married couple cannot give birth to a child, she can be asked to make sexual intercourse with abagirwa in order to benefit from the chance of the spirits.

The phenomenon of drunkenness is reported as extended impact of traditional believes on anthropological status. First they used harmful alcoholic beer called inturire brewed with honey or kanyanga ${ }^{16 .}$ In order to eliminate the stress they have recourse to beer as tranquillizer. Sometimes they say the beer taking is a condition from ancestral spirits.

\footnotetext{
15 Smith, Melinda 2008.

${ }^{16}$ Kanyanga is a toxic alcohol made out of bananas
} 


\section{Dr. Hakizimana Lucien et al.}

\subsection{Consequences of Abagirwa's Shamanism on Social Welfare of Children}

Children from the family of mad persons ancient practitioners of abagirwa's shamanism, lack education on different forms. As their parents don't have sufficient control, they can't provide with necessary needs to maintain their children educated.

Children dropout out of school by the lack of school material and other basic needs. The poverty due to the time spent by taking care for the mad persons increases the vulnerability of children.

Lack of adequate health care of children is a great problem. The hygiene, the malnutrition and the lack of health insurance fees are reported by different mad people. In fact the groups in which they are gathered are unable to fulfill different needs felt by them.

The imposition of belief to the children is a great problem. In most cases children are obliged to practice the shamanism belief of the parents.

The poverty is felt by the practitioners of this shamanism. In fact in their practices, people are asked to provide with the sacrifice of a cow, a goat or a sheep,.... This contributes to the impoverishment of the family. Even if those ancient practitioners don't want to point it, some said that the illnesses are consequences of skipping the practices and the fact of having stopped to provide those sacrifices.

The discrimination and isolation of practitioners from the society is felt. Some respondents said that children whose parents still practicing abagirwa's shamanism are isolated from the society, at school and they are discriminated.

Victims as personal sacrifice: many children as believe the members of group focus we met affirm that some children are offered as sacrifice to the spirit of Nyabingi and her descend shamanism. It is why they believe that the crazy persons often met in the villages have been offered as victims to those spirits. The disabilities of children which are numerous in the zone are felt because they are sacrificed to those spirits.

Several authors have been critical of belief indoctrination of children, such as Daniel Dennett (2006) and Richard Dawkins. Christopher Hitchens and Dawkins use the term child abuse to describe the harm that some belief upbringings inflict on children. ${ }^{17}$

Dawkins has written a children's book that seeks to convince them of what he deems to be the fallacy of various belief teachings. ${ }^{18} \mathrm{He}$ asks how a young child can be considered intellectually mature enough to have such independent views on the cosmos and humanity's place within it. ${ }^{19}$

\section{CONClusion}

As matter of conclusion, along this research we have argued around the adherence to abagirwa's shamanism and its effects on anthropological status of mad people of Gitenga Cell, Kiyombe Sector in Nyagatare District. Findings confirmed undermining psycho-social and biological effect of practicing abagirwa's shamanism such as cases of suicide or attempt to suicide $68 \%$, incest $46 \%$, divorce $90 \%$, the parents who do not care about the health of their children $65 \%$, clinical depression $100 \%$, denial of the efficiency and effectiveness of pharmaceutical medicines $80 \%$, alienation $100 \%$. These results are confirmed also by mentioned sources such as different articles from scientific journals and books.

Strategies suggested for the effectiveness of anthropological wellbeing:

$80 \%$ of the respondents said that the education should help them to change their behaviors. This education for them must begin from the level of family. In different occasions, persons habilitated can intervene to educate the population on different effects of having unsafe believes.

$100 \%$ of the respondents said that local and opinions leaders at different levels can include in their interventions the rights of people and different laws often infringed by leaders of abagirwa's shamanism. The rights to safe health, to safe belief, to the protection from different harms are to be included in their intervention in order to discourage the practitioners and their leaders.

\footnotetext{
${ }^{17}$ Christopher Hitchens and Dawkins, 2006:19

${ }^{18}$ Richard Dawkins 2006.

${ }^{19}$ Dawkins's 2006.
} 
The mad persons need to be rehabilitated. In fact, the mad people or those in recovery need a particular center and particular treatment by specialists. In fact, as said the care givers of the mad persons at Nyarurema Center, their intervention is limited on visiting the mad people, encouraging them to take pharmaceutical drugs, and accompany them to health centers, hospitals or to psychiatric center of Ndera. No follow up of evolution, no sensitization of the population are not deepened. This anthropological rehabilitation can touch all the strata of the population.

The persons consulted said in order to discourage the practice of abagirwa's shamanism which prevent the population the development and which alienate the people, the laws on shamanic practices must be divulgated and consolidated. This can help the ignorant people to benefit from their rights. To prevent ambiguity and psychological sufferings to practitioners,${ }^{20}$ traditional healing and its medicines must be deepened with scientific and rigorous methods so that to avoid disappointing practices.

\section{REFERENCES}

Bernard, H.R. (2002). Research Methods in Anthropology: Qualitative and quantitative methods, 3rd edition, Alta Mira Press, Walnut Creek, California.

Carolyn Boyce et Palena Neale, (2006) Conducting in-depth interviews: A Guide for Designing and Conducting In-Depth Interviews for Evaluation Input, Pathfinder international, Watertown, USA.

Dawkins, Richard (2006). The God Delusion. Boston: Houghton Mifflin.

Dennett, Daniel (2006). Breaking the Spell. New York: Viking

Eliot \& Associates (2007) Guidelines for Conducting a Focus Group [online] available fromhttp:// cp0.ipnshosting.com/ focusgro/documents/How_to_Conduct_a_Focus_Group.pdf Retrieved on 21st March 2017.

Gerard Niyomugabo, (2013). Umusogongero ku ijambo ry'Imana y’i Rwanda, Kigali, Style Ltd.

Laurent Magesa (1997). African religion. The moral traditions of abundant life, Nairobi: Pauline's Publications Africa.

Longo, Dan L (2012). Seizures and Epilepsy, Harrison's principles of internal medicine (18th ed.). McGraw-Hill.

Martin N Nkemnkia, (1999). African Vitalogy, Nairobi, Kenya, Paulines.

Michael C Kirwen, (2008). African Cultural Domains, life cycle of an individual, Book 1, Nairobi, Kenya, Mias Books.

Michael C. Kirwen and alii (2011). African Cultural knowledge: Themes and embedded beliefs, Nairobi: Mias Books.

Mousa A. Masadeh, (2012). "Focus Group: Reviews and Practices", International Journal of Applied Science and Technology, Vol. 2 No. 10; December 2012.

Neel Burton M.D., (2012). Madness, Creativity, and Religious Experience, New York: Sussex Publishers.

Philip Briggs, Janice Booth, (2009). Rwanda, USA: The Globe Pequot Press.

Picchioni MM, Murray RM (2007). Schizophrenia, British Medical Journal 335 (7610): 91-95.

R.J. Schreiter, (1985). Consulting local Theologies, New York: Orbis Books.

Smith, Melinda (2008). Anxiety attacks and disorders: Guide to the signs, symptoms, and treatment options. Retrieved from http://www.anxietycentre.com/anxiety-symptoms.shtml Retrieved on 4th December 2016.

Wertz, Charmaz, McMullen. (2011). Five Ways of Doing Qualitative Analysis: Phenomenological Psychology, Grounded Theory, Discourse Analysis, Narrative Research, and Intuitive Inquiry, New York: The Guilford Press.

${ }^{20}$ R.J. Schreiter, 1985. 